\title{
Editorial
}

\section{Entendendo o ressurgimento e o controle do sarampo no Brasil}

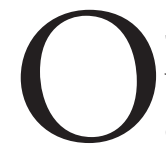

sarampo é uma doença de alta transmissibilidade causada por um vírus RNA, gênero Morbillivirus, família Paramyxoviridae. Um doente é capaz de transmitir para outras 12 a 18 pessoas. Outra característica do sarampo é o período longo de transmissibilidade do vírus: seis dias antes do exantema a quatro dias depois do seu aparecimento. ${ }^{(1)} \mathrm{O}$ sarampo estava controlado nas Américas e o Brasil recebeu o certificado de erradicação em 2016 e perdemos no final de 2018, pelo avanço dos surtos que estão ocorrendo até os dias atuais. ${ }^{(2,3)}$

O sarampo é uma doença potencialmente grave que cursa com febre, coriza, conjuntivite e manchas vermelhas pelo corpo, que tem início na regiáo retroauricular e dissemina-se para rosto, tronco e membros: chamada de distribuição craniocaudal. As clássicas lesōes de Koplik, que são lesôes de 2 a $3 \mathrm{~mm}$ de diâmetro, discretamente elevadas, de cor branca com base eritematosa, localizadas na regiáo interna da mucosa oral, na altura do segundo molar superior, estáo presentes em alguns casos, antes do exantema e desaparecem em 48 horas. O sarampo tem a capacidade de deprimir a resposta imune para outros patógenos. Assim, a doença pode evoluir com complicaçôes infecciosas bacterianas como a otite média e a pneumonia, especialmente em crianças menores de cinco anos, desnutridos e imunodeprimidos. O sarampo em crianças com deficiência de vitamina $\mathrm{A}$ associada a desnutrição tem evoluçáo mais grave e pode causar cegueira. Uma outra complicação crônica rara (incidência de 4 a 11 casos por 100.000 pessoas) é a panencefalite esclerosante subaguda, doença degenerativa que afeta crianças e adultos jovens causada pela infecção persistente do vírus no encéfalo com consequente resposta imunológica crônica. ${ }^{(1)}$

A infecção por sarampo durante a gravidez está associada ao aumento do risco de complicaçóes, incluindo aborto, parto prematuro, doença neonatal, baixo peso ao nascer e morte materna. Embora, os estudos não são conclusivos quanto ao efeito teratogênico do vírus do sarampo. Importante, a gestante náo pode ser vacinada, pois a vacina é feita de vírus vivo atenuado. Assim como os imunodeprimidos, a prevenção da infecção na grávida deve ser realizada a profilaxia pós-exposiçáo com imunoglobulina endovenosa.

Por que o sarampo ressurgiu no Brasil? Casos notificados de sarampo no mundo cresceram 300\% nos primeiros três meses de 2019, em comparação com o mesmo período de 2018. A Organização Mundial de Saúde alertou que até o final de março de 2019, 170 países haviam notificado $112.163 \mathrm{ca}-$ sos de sarampo. ${ }^{(2)} \mathrm{O}$ genótipo que está envolvido no surto no Brasil é o D8, 
o mesmo que se disseminou na Europa e na Venezuela, Colômbia e diversos outros países da América Latina.

$\mathrm{O}$ vírus entrou no Brasil junto com turistas e migrantes susceptíveis que desenvolveram a doença. Encontrou baixa cobertura vacinal, inferior a 95\%, inicialmente na região Norte do país. Posteriormente, foi introduzido e disseminou-se para áreas mais populosas como a regiáo sudeste, com maior impacto na grande São Paulo. Apesar da cobertura vacinal para sarampo na cidade de São Paulo, em torno de 90\%, não foi suficiente para conter o surto. Atualmente, sarampo está disseminando-se para diversos estados brasileiros. Até outubro de 2019, foram notificados 49.613 casos suspeitos de sarampo no Brasil. Desses, já foram confirmados 10.429 (21,0\%) casos, sendo 8.235 $(79,0 \%)$ por critério laboratorial e $2.194(21,0 \%)$ por critério clínico epidemiológico. ${ }^{(3)}$ Coberturas vacinais superiores a $95 \%$ são o meio mais eficaz de manutenção de uma população livre do sarampo, chamada de imunidade de rebanho, impedindo a circulação do vírus, caso seja introduzido algum caso.

A vacinação contra sarampo é segura e é a forma mais eficiente de prevenir a doença. Infelizmente, temos grupos anti-vacinas no mundo inteiro, alguns em comunidades religiosas e por outro lado, pais com informaçóes equivocadas. A divulgação de falsas informaçóes sobre vacinas nas redes sociais, como relacionada a graves eventos adversos, influenciam muitas pessoas a não vacinarem seus filhos e não se vacinarem, aumentando o número de susceptíveis, facilitando o ressurgimento de doenças já eliminadas.

O atual calendário de vacinação do Ministério da Saúde do Brasil inclui duas doses de vacina para sarampo associada a proteção para outros vírus. A primeira dose da vacina tríplice viral (sarampo, caxumba e rubéola) é aplicada aos 12 meses de idade e uma segunda dose da vacina tetra viral (sarampo, caxumba, rubéola e varicela) aos 15 meses de idade. Os profissionais de saúde devem tomar duas doses de vacina, caso não tenham tomado após os doze meses de idade e manterem seu esquema de imunização atualizado.

As entidades de saúde pública municipal, estadual e federal têm realizado suas açóes priorizando a cadeia de transmissão, aplicando vacinaçóes de bloqueio em hospitais, escolas, instituiçóes e na comunidade. A vacinação de bloqueio é uma estratégia que tem se mostrado eficiente. No Hospital São Paulo, UNIFESP (HSP-UNIFESP), no dia 20/06/2019 foi identificado um aluno do sexto-ano de Medicina com suspeita de sarampo (confirmado posteriormente) que estava realizando seu estágio no HSP-UNIFESP. Imediatamente, após a notificação do caso, foi iniciado a vacinação de bloqueio nos profissionais, com foco nos contatos. Foram aplicadas em quatro dias, 1250 doses de vacina. Nenhum caso foi notificado em alunos e profissionais do hospital nos 30 dias subsequentes. Essa não foi uma experiência isolada, a vacinação de bloqueio na suspeita de um caso de sarampo, foi utilizada em outras instituiçôes como uma estratégia exitosa.

O sarampo é doença de notificação compulsória e deve ser notificada na suspeita para que sejam tomadas as medidas necessárias de bloqueio.

Poucos casos de sarampo têm sido internados e, até o momento, a doença tem se mostrado de evolução menos grave do que conhecemos no passa- 
do. Outro fato, temos visto casos de sarampo em pessoas que tomaram duas doses de vacina na infância e desenvolveram a doença, alguns, inclusive, com IgG positiva para sarampo na suspeita da infecção, o que é indicativo de exposição prévia ao vírus vacinal ou selvagem. Embora estes casos sejam minoria, é possível que o nível de anticorpos se reduza com o passar do tempo ou a resposta imunológica ao genótipo D8 seja menos eficiente, além de fatores genéticos, porém, apenas hipóteses para explicar situaçôes clínicas que estamos vivenciando neste surto. ${ }^{(4)}$

Outra preocupação é a transmissão intra-hospitalar. Todo paciente internado com sarampo deve ser isolado em quarto único ou coorte e mantido em precauçóes padrão e para aerossóis. Deve ser oferecido ao doente, durante $\mathrm{o}$ atendimento da emergência, máscara tipo cirúrgica para evitar a dispersão de gotículas e o profissional de saúde deve utilizar máscara PFF2 (proteçẫo facial tipo II - N95) durante todo o atendimento. ${ }^{(5)}$

É interessante observar que diversas doenças infecciosas que ressurgiram recentemente, alteraram sua história natural, tanto o quadro clínico como a cadeia epidemiológica. Com os recursos diagnósticos e técnicos atuais está sendo possível conhecer melhor a patogênese e as medidas de controle a exemplo da febre amarela, toxoplasmose, hepatites virais e mais recentemente o sarampo. É fundamental aproveitarmos estas oportunidades para ampliarmos a pesquisa e o ensino das doenças infecciosas.

\section{Prof. Dr. Eduardo Alexandrino Servolo Medeiros} (https://orcid.org/0000-0002-6205-259X)

Prof. Associado da Disciplina de Infectologia e Presidente da Comissão de Controle de Infecção Hospitalar e Programa de Antimicrobial Stewardship do Hospital São Paulo, Escola Paulista de Medicina - Unifesp. Pesquisador do Conselho Nacional de Desenvolvimento Cientifico e Tecnológico-CNPq.

Como citar:

Medeiros EA. Entendendo o ressurgimento e o controle do sarampo no Brasil. Acta Paul Enferm. 2020;33:e-EDT20200001

DOI:http://dx.doi.org/10.37689/acta-ape/2020EDT0001

\section{Referências}

1. Strebel PM, Orenstein WA. Measles. N Engl J Med. 2019. 25;381(4):349-57.

2. Organização Pan-americana da Saúde, Organização Mundial da Saúde. Sarampo [Internet]. Brasília (DF): OPAS; 2019. [citado 2019 Nov 14]. Disponível: https://www.paho.org/bra/index.php?option=com_conte nt\&view=article\&id=5633:folha-informativa-sarampo\&ltemid=1060 
3. Brasil. Ministério da Saúde. Boletim Epidemiológico [Internet]. 2019; 50(33). [citado 2019 Nov 14]. Disponível em: https://portalarquivos2.saude.gov.br/images/pdf/2019/novembro/07/Boletimepidemiologico-SVS-33-7nov19.pdf

4. Plotkin SA. Measles: Breakouts and Breakthroughs. J Pediatric Infect Dis Soc. 2019 25;8(4):289-290.

5. São Paulo. Prefeitura do Município de São Paulo. Secretaria Municipal da Saúde. Coordenadoria de Vigilância em Saúde. COVISA. Biossegurança no atendimento de pacientes com sarampo nos estabelecimentos assistenciais de saúde. Informe Técnico. 06/DVE/2019, 15 de julho 2019. 